\title{
The Politics of Knowledge: Knowledge Management in Informal Settlement Upgrading in Cape Town
}

\author{
Floortje Jacobs ${ }^{1}$ - David Jordhus-Lier ${ }^{2}$ • \\ Pamela Tsolekile de Wet $^{3}$
}

Published online: 27 June 2015

(C) Springer Science+Business Media Dordrecht 2015

\begin{abstract}
In situ solutions, participatory practices and the inclusion of community knowledge have become key ingredients in urban upgrading policies across the world. Knowledge, however, is not neutral, but value-laden, representing different and conflicting interests. Including community-based knowledge, therefore, is far from straightforward. To understand the politics of urban development interventions, a deeper conceptualisation of the relationship between knowledge and power is required. This article tries to contribute to this conceptualisation through an empirical analysis of informal settlement upgrading. Specifically, it interrogates the role of community knowledge in urban development through a study of two informal settlements in Cape Town. Findings from this qualitative research contradict the notion of a unified community whose 'community knowledge' can be engaged with. In both settlements, knowledge politics have resulted in tensions within the settlement, creating new interest groups and knowledge alliances, showing the complex interconnectedness of knowledge, power and mobilisation. As knowledge has been built, used, exchanged and contested to upgrade livelihoods, this knowledge has been standing in a mutually constitutive relationship with collective action.
\end{abstract}

Keywords Urban governance · Urban development · Mega-projects · Housing · Participation $\cdot$ Knowledge

David Jordhus-Lier

david.jordhus-lier@sosgeo.uio.no

1 Planning and International Development Studies, Department of Human Geography, University of Amsterdam, Plantage Muidergracht 14, 1018 TV Amsterdam, The Netherlands

2 Department of Sociology and Human Geography, University of Oslo, Moltke Moesvei 31, 0851 Oslo, Norway

3 African Centre for Citizenship and Democracy (ACCEDE), University of the Western Cape, Robert Sobukwe Road, Bellville 7535, Republic of South Africa 


\section{Introduction}

In situ solutions, participatory practices and the inclusion of community knowledge have become key ingredients in urban upgrading discourse, both the policy documents of international development organisations and, gradually, as they are expressed in urban policy frameworks. This article interrogates the role of community knowledge in urban development through an empirical analysis of informal settlement upgrading initiatives in a Southern African city. We base our analysis on the assumption that knowledge is not neutral, but value-laden, representing different and conflicting interests. Hence, seeing knowledge and power as closely related is essential if we are to understand resistance to urban development interventions. In this article, we will first briefly review the existing literature on knowledge and power in urban governance in order to better explain the political nature of knowledge in the context of social mobilisation. We will then present findings from qualitative research on two informal settlements in Cape Town, where the role of knowledge has been contested during recent upgrading and development initiatives.

\section{The Politics of Knowledge}

As no single definition of knowledge exists in academic literature, the concept itself has been subject to debate (see Fischer 2000; Bruckmeier and Tovey 2008). An important distinction can be made between 'knowledge' and 'information', where information consists of data and facts which can easily be transferred or shared. To build knowledge from information, context and applied experience is required. Thus, knowledge rests on the values and meaning of different actors (Hordijk and Baud 2006). This means that knowledge is political by nature.

Literature on urban development tends to operate with quite different conceptualisations of knowledge and power. One the one hand, several authors apply a wide definition of knowledge that encompasses values and world views of different subjects - much in the same way as expressed in the colloquial phrase 'this is common knowledge'. For example, the influential adaptation of Foucault of Flyvbjerg and Richardson (2002) promotes the view that behind all production of knowledge lays a struggle over truth between different interests. Real-life rationalities are the outcome of such contestation, and these rationalities are allowed to dominate as 'common knowledge' in urban governance. The critical question to ask from this point of view is not, therefore, 'whose knowledge is included?' Such a search for inclusion would, following the argument of Flyvbjerg and Richardson (2002), constitute a Habermasian idealism. Rather, researchers should ask how different actors are constructing different rationalities, sometimes directly competing with each other, to achieve certain goalsthereby acknowledging the productive nature of knowledge power. Watson (2003) and Massey (2013) have tried to apply a similar lens on informal settlement upgrading in Cape Town, stating that merely bringing local communities on board in design and planning processes will not solve anything as long as the main rationalities of the state and poor urban dwellers remain incompatible. According to these authors, the state wants to govern these areas in the most efficient way possible and also remake poor 
people into ratepayers, while residents of informal communities assume very different rationalities of survival and reciprocity.

Other studies of urban development have chosen a more narrow understanding of knowledge, as contextualised information that can be shared between different actors or withheld from them. This conceptualisation can also be found in colloquial use, such as in the phrase 'not to my knowledge'. A narrow use of the term does not entail that knowledge is seen as free from power relations, but rather that there are pertinent research questions to be asked about how knowledge is managed and whose knowledge is included in urban planning and decision-making. For instance, the study by Auyero and Swistun (2008) of community perceptions of toxins in an Argentinian shantytown clearly distinguishes between erroneous perceptions and factual knowledge about pollution, in contrast to Flyvbjerg's relativisation of truth. Still, they explain the uncertainty people expressed as partially stemming from powerful outside actors with vested interests.

Van Ewijk and Baud (2009) have identified different types of knowledge in such governance arrangements. They distinguish between tacit, contextualembedded and codified forms of knowledge. Tacit knowledge is built through experience and practise. It often remains non-codified and comes into existence through individual experiences by being transferred from person to person. Contextual-embedded knowledge is also built through practice but is more widespread, systematised and recognised than tacit knowledge. Van Ewijk and Baud (2009) distinguish three sub-types of contextual-embedded knowledge: technical and economic knowledge, which often is sectorally embedded through professionals; community-based knowledge spread by local social networks; and political knowledge embedded in political networks and institutions. Van Ewijk and Baud (2009) also identify codified knowledge, which is systematically expressed and codified by planners and academics as statistics and models. This view promotes knowledge building which is not merely expert-led, but rather balanced and confronted by community-based knowledge and working experience (Fischer 2000; Van Ewijk and Baud 2009).

While we acknowledge that a broad conceptualisation of knowledge as produced by rationalities holds crucial insights into the limits of knowledge management, we argue that there are reasons for employing a more narrow understanding of knowledge when studying informal settlement upgrading. We agree with the authors above claiming that all knowledge is shaped by the worldviews of the subjects producing it. Still, we find that asking questions such as 'to what extent have the viewpoints and experiences of local communities been included in decision-making?' is both relevant and pertinent. Of course, knowledge exchange is never static. We attempt to be sensitive to the processes at play by asking, to the extent that community knowledge has been included, at what stage in the upgrading process has this been done? Finally, we are also interested in the actors through which this knowledge exchange has been facilitated. By way of summary, the following article tries to combine the insights of those who emphasise the contested rationalities of knowledge production and those who see a potential for empowerment in the more technical aspects of knowledge management. 


\section{Knowledge Management in Urban Localities}

To further a notion of knowledge as relational, political and pluralist, we make a conceptual distinction between knowledge building, use, exchange and contestation. Bruckmeier and Tovey (2008) refer to this as the 'knowledge-embedding model', based on the idea that knowledge processes are driven by power struggles between groups for recognition of their definitions of problems and embedded in social institutions. Baud et al. (2011) argue that there are contrasting ways of approaching knowledge-building processes. Some assume scientific codified knowledge is being built up in linear processes of experimentation, verification and codification (Gibbons et al. 1994). This process relies heavily on expert knowledge systems and is the assumed model of knowledge building in government-private sector relations. This model is criticised, as it assumes that knowledge is universally applicable and therefore ignores context. Baud et al. (2011) favours a different approach, where different types of knowledge are assumed to interact through social processes, in which various paradigms compete with each other through institutions. In this way, knowledge building is seen as a conflictprone process. This type of meaningful knowledge construction is important but unruly, especially in pluralist, multi-stakeholder governance arrangements (Baud et al. 2011).

Knowledge use refers to the appropriation of knowledge by policymakers. Knowledge always serves someone's purpose and represents someone's views (Epstein 1996; Haraway 1988). Accordingly, Hordijk and Baud (2006: 669) argue that there is a 'connection between fact and value, between knowledge and practice, and between the knower and the known'. Knowledge always changes when it is reproduced, as it is filtered according to the perspective of different actors, reflecting their context and understanding (Hjorth 2003). Consequently, Hordijk and Baud argue that both governance institutions and the research community need to 'reflect the variety of knowledge existing among actors involved in urban governance, and the conflicts in interpretation and valuation of knowledge sources' (2006: 669).

Knowledge exchange refers to the sharing of contextualised information between different actors. Hordijk and Baud (2006) uphold that, in general, knowledge tends to stay where it is generated. For instance, research results are often retained by universities and organisations funding the research. Scientific insight does often not reach authorities and practitioners but remain in academic circles. Conversely, local communities can be unwilling to share their experiences with policymakers, afraid that it will be used against them (Patel et al. 2012). Both powerful and marginalised actors might have rational reasons for not engaging in knowledge exchange. Nonetheless, this reduces the potential for mutual learning when actors bring in complementary resources (Baud and Post 2002). Therefore, Hordijk and Baud (2006) have argued that urban governance arrangements should be constructed in ways that encourage the exchange of different types of knowledge between researchers, policy makers, civil society actors and community members (see also Corburn 2003).

The potential for knowledge exchange notwithstanding, not every type of knowledge is valued equally in urban governance arrangements. Knowledge contestation occurs when actors attempt to use their knowledge strategically for particular interests. While various 'communities of interest' can make knowledge claims regarding urban development processes (Scott 2011), the legitimacy of such claims tends to rest with the status of different types of knowledge as identified by Van Ewijk and Baud (2009). An 
illustration is given by Hordijk and Baud (2006) by naming the controversy over numbers; while numbers initially seem 'objective', they can also become a political factor. For example, in projects concerning sub-standard settlements, population size can be contested as governments exclude people who live illegally in houses (Patel 2001).

Generally, it is argued that there is a tendency in urban governance to focus on codified facts and technical information rather than on contextual knowledge. In other words, codified knowledge is considered more legitimate than the use of other types of knowledge (Hordijk and Baud 2006). Even in deliberative processes, meant to include knowledge of all actors, expert scientific knowledge often has greater power and legitimacy (Scott and Barnett 2009). Government officials and business actors often use scientific knowledge to claim authority and increase their influence in decisionmaking (Hordijk and Baud 2006). This perceived legitimacy of science also means that science is often brought in to settle controversies, which Epstein (1996: 6) calls the 'scientisation of politics'. Epstein (1996) argues that this simultaneously leads to the 'politicisation of science', as different stakeholders will bring in their own experts to support their interests, and political disputes tend to become technical disputes. This struggle over the legitimacy of data has implications for all stakeholders and often creates internal and external challenges, also with regard to community leadership (Patel et al. 2012), which will be demonstrated through our two cases.

\section{Whose Knowledge?}

Increasing attention is given in academic literature to the potential contribution of alternative types of knowledge to governance processes, particularly from civil society and local communities. Decentralisation and democratisation have served to increase the authority of local governments in many developing countries during the last decades (Rakodi 2003). Attention for alternative types of knowledge resonates with this decentralisation agenda, which acknowledges the potential of decentralised governments to be knowledgeable about local situations, and promotes the incorporation of community-based knowledge in decision-making (Rakodi 2003). Locally produced knowledge can contribute to more realistic planning decisions sensitive to the needs of targeted groups and increase a local sense of ownership (Corburn 2003). Also, when local knowledge is included, Hordijk and Baud (2006) have observed that policy agendas tend to become more problem-oriented. In short, the inclusion of community knowledge has been upheld as a path to better decision-making, more legitimate governments and an expanded notion of citizenship (Boulding and Wampler 2010; Cornwall and Coelho 2007).

Literature has documented cases where scientific knowledge has been challenged by alternative types of knowledge, leading to the repositioning of science in political affairs (Fischer 2000; Scott 2011). Civil society organisations often employ scientific technologies to formalise or spatialise community knowledge in order to be taken more seriously. This so-called 'civic science' is defined by Scott (2011) as knowledge production by civil society which claims to be valid and reliable scientific knowledge. Such exercises might lead certain citizens to acquire expert status, what Epstein (1996) labels the 'expertification of lay activists'. Scott (2011) argues that civic 
science has the potential to democratise knowledge production in urban decisionmaking processes. This type of knowledge building enables communities to mobilise knowledge about themselves in a manner that can advance their own rights, resources and claims (Appadurai 2012). Moreover, through these processes, boundaries between experts and communities become fluid, hybrid identities emerge, and the way contested issues are understood by the public change (Leach and Scoones 2007). In decisionmaking processes, both those who govern and the governed tend to 'shop' for knowledge that fits their interests and form alliances accordingly. These knowledge alliances are always shaped by social interests, interacting in highly politicised fields (Leach and Scoones 2007). In other words, knowledge alliances are not static, but subject to change.

For people living in informal settlements, the issues identified above are arguably even more acute than for others. The mere fact that their residential spaces are labelled as 'informal' implies that they lack recognition in formal systems of spatial knowledge, such as planning maps. Moreover, Hordijk and Baud (2006) state that flows of knowledge between marginalised communities to authorities are vulnerable to interference, who can exclude alternative types of knowledge by contesting their legitimacy. The views and knowledge of informal settlement dwellers, often presented in the form of narratives and experiential accounts, are often regarded as 'too subjective' (Scott 2011). At the same time, communities can be strategically denied access to scientific knowledge by officials, if it is perceived to threaten their agenda. By conducting their own analyses, citizens can be able to define their own priorities (Chambers 1995).

Importantly, these insights should not lead us into a romanticised and naive understanding of community knowledge. Like all other forms of knowledge, community-embedded knowledge is partial and tends to be dominated by powerful actors, prompting us to look at the inclusion of other knowledge forms through a critical lens. By way of summary, even in inclusive urban governance processes, there is no guarantee that community knowledge is meaningfully included. In South Africa, post-apartheid housing policies have slowly become more inclusive, at least on paper, and more attentive to community consultation (Huchzermeyer 2011). Still, a gap often remains between normative expectations and empirical realities of participation (Cornwall and Coelho 2007). How power relations constrain knowledge use and exchange in particular governance arrangements must therefore be determined through empirical research. This is the task of the remainder of this article.

\section{Researching Informality}

Our primary data is drawn from two main sources. First, we use the qualitative interview material from an MA research project (Jacobs 2013), which includes interviews with project managers and political authorities related to the N2 Gateway Project, as well as local leaders and representatives. Secondly, we use interviews with key informants of both settlements, including 25 interviews with residents of Joe Slovo, from a comparative research project in which the two other authors have been involved. 
In addition, a series of interviews with local political leaders and city managers have been conducted since 2009 .

In preparation for the resident interviews, conversations with different stakeholders in Joe Slovo have been undertaken. Residents interviewed were asked to nominate friends and neighbours to participate through a 'snowballing technique'. For most interviews, a local assistant helped translating from isiXhosa to English, and these translations were edited and quality-checked.

A similar study in Europe informal settlement was attempted but could not be realised due to access problems. While this process was frustrating on the part of us as a research team, it was very indicative of the politics of knowledge in informal settlements which we analyse. We were therefore left a series of interviews with previous and current community leaders in Europe and a small number of resident interviews. These were supported by interviews with NGOs and academic representatives involved in this settlement. In addition, the published reflections of Winkler (2013) on the engagement between residents of Europe and students at the University of Cape Town represent an additional source for our discussion.

\section{Two Informal Settlements Along the N2 Highway}

We use the experiences of two informal settlements along the N2 highway in Cape Town, to see how knowledge management strategies have met various responses from local communities. Joe Slovo forms an outer band surrounding Langa, the oldest black township in Cape Town. The Joe Slovo informal settlement was established in 1990 by people from Langa who were residing in backyard shacks and by migrants looking for jobs (Eppel 2007). Joe Slovo is closest to the city centre of all Cape Town's major informal settlements and is therefore, in relative terms, an attractive destination for poor job seekers. Electricity, communal toilets and waterborne sewerage were installed by the municipality in 2003 (Huchzermeyer 2011). In 2004, the N2 Gateway Project was initiated by all three tiers of government and conceived as a pilot for the national government's new housing policy, Breaking New Ground. It aimed to upgrade settlements visible from the N2 highway, with the development of the Joe Slovo settlement as a showcase. In September 2004, residents were presented with these plans through local media. In 2005, phase I was launched and resulted in relocation of shacks and the construction of 700 rental units. In 2006, phase II was launched, consisting of some subsidy houses for poor residents and mortgaged housing for a higher-income bracket. In 2011, phase III was launched which offered almost 3000 fully subsidised units for informal settlement dwellers. Protests and court cases led up this significant change in housing allocation for phase 3, as Joe Slovo's residents had become angry about the first phases not benefiting them (Author 2014).

The Europe informal settlement in the Gugulethu township, together with three other settlements, forms a continuous strip of shacks stretching several kilometres along the N2 highway near Cape Town International Airport. According to an enumeration research conducted by the Community Organisation Resource Centre (CORC) in 2010, inhabitants claim to have lived there for more than 20 years. The site is deemed unsuitable for rehabilitation by planners, and life in Europe is marked by environmental hazards such as flooding, drainage problems, high-density building and a lack of basic 
infrastructure and services. Europe is a chronically under-serviced area and benefits from NGOs including health and church-based organisations (Fig. 1).

The wards where Europe and Joe Slovo informal settlements are located are among the poorest in the city, according to the city's socio-economic index. Hence, it comes as no surprise that residents in Europe and Joe Slovo have taken part in service delivery protests that have become widespread across urban South Africa. Both in 2007 and in 2013, the informal settlement population made use of their strategic location in Cape Town to blockade the adjacent N2 highway as a political protest against poverty and exclusion.

Residents of Joe Slovo have, ever since the first plans for the N2 Gateway Project were unveiled, been caught up in contestation surrounding the development of formal housing. Their mobilisation has accompanied the various phases of the project, but since 2011, the most important form of organising has been through the Joe Slovo Task Team, which consists of young leaders from the community. The Task Team facilitates community consultations, relocations, demolition of old shacks and the allocation of new housing units in a relatively technocratic manner, almost to the point of demobilisation of the local community (Author 2014). Residents in Joe Slovo have been confronted with different types of expert knowledge in each phase of the

\section{Case study settlements in Cape Town}

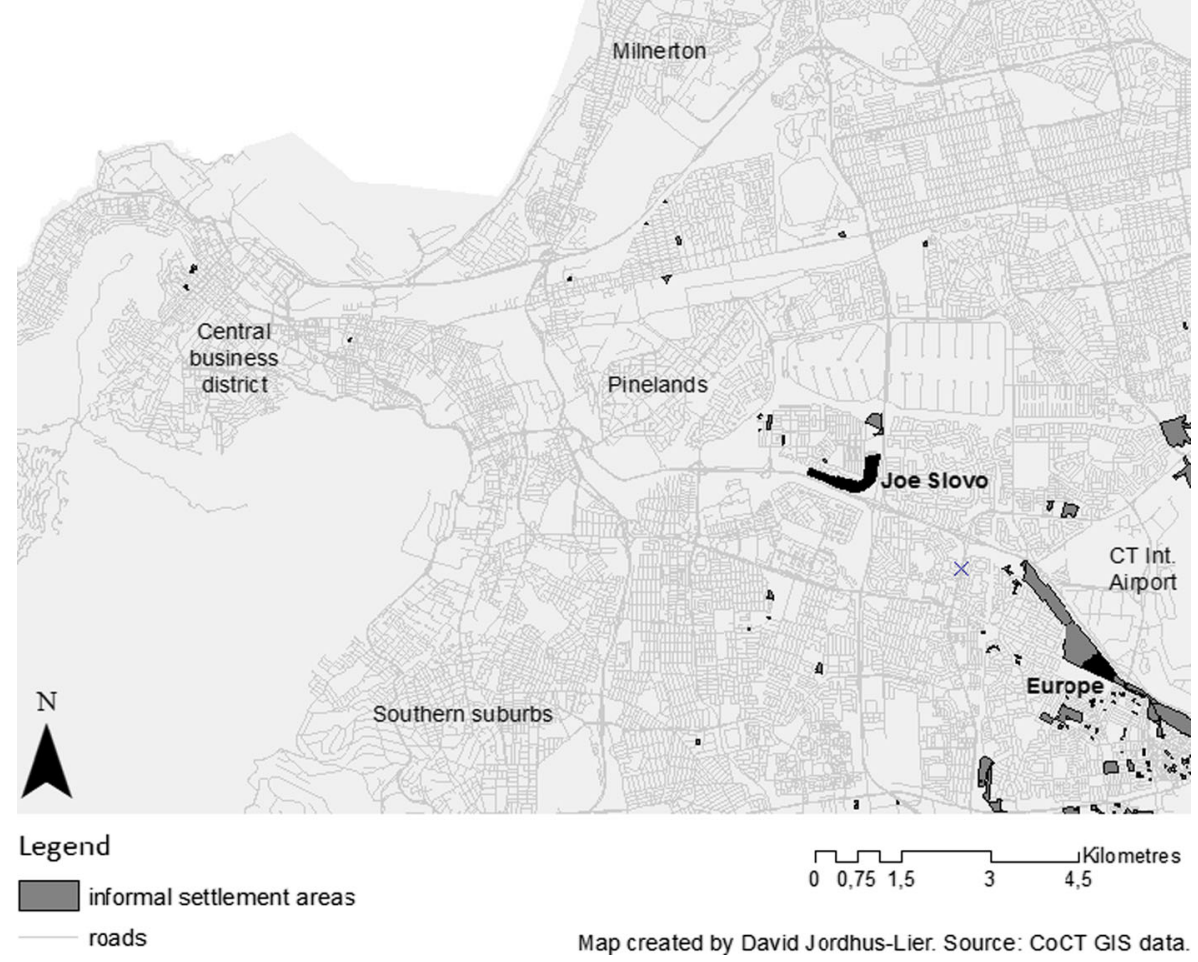

Fig. 1 Case study settlements in Cape Town. Source: Author (2015) 
project-legal, political, bureaucratic - and have, as will be shown below, sought recognition for their community knowledge since the project started.

In the Europe settlement, the pattern of contestation has differed. Early on in the N2 Gateway Project, Europe and adjacent settlements were ruled out of the development as they were deemed to be located on hazardous land, a previous municipal landfill site. Thus, in a period when Joe Slovo residents have seen a fundamental transformation of their built environment, very limited upgrading has taken place in the Europe settlement. This, however, does not entail lack of mobilisation in the local community. Paradoxically, while residents have disputed experts' claiming their land is unsuitable for rehabilitation, upgrading initiatives in Europe has also been met with community resentment.

In both cases, expert and community knowledge have become politicised. In the following sections, we identify six aspects of knowledge building and use which has appeared crucial in the two cases under study. These are (i) the definition and demarcation of local constituencies, (ii) the mediation of information flows and knowledge forms, (iii) the timing of knowledge exchange and participation, (iv) the legitimacy of different knowledge forms, (v) the ownership of knowledge and, finally, (vi) perceived risks associated with the exchange of information.

\section{Defining the Community}

A premise for participatory knowledge management practices and the inclusion of community knowledge is a meaningful identification and demarcation of the local constituencies with which to engage. Frazer (2000:76) describes a community both as a shared value - bringing together elements of solidarity, commitment and trust - and as a common place, where people share a locality, historical networks, a religion, an interest or a cause. In Joe Slovo and Europe, community value and place do not always overlap, as a majority of residents are first-generation urban dwellers.

While different voices in the N2 Gateway Project had been advocating for 'including the community' in planning and implementation (Jacobs 2013; Jordhus-Lier 2015), defining 'the community' proved tricky. In the early phase of the project, Eppel (2007) found recurring tensions between informal settlement dwellers in Joe Slovo and backyard dwellers in the surrounding Langa township, framed as a conflict between newcomers and poor people born in the city. Furthermore, the sense of community within the Joe Slovo informal settlement has disintegrated into competing factions as the project progressed. By 2011, the community was split between rival leadership groups, roughly corresponding to those eligible and those not eligible for housing. The Joe Slovo Task Team faced opposition from a grouping known as the Joe Slovo's Residents' Association. Originally, it had represented various street committees in the settlement but had been marginalised since the start of the project. At the time of research, the Residents' Association represented people who were critical towards the project. How each of these different actors was accepted by project management and other authorities determined their access to information and the extent to which their concerns were deemed legitimate.

Similarly, the Europe informal settlement also represented a contested social constituency. On the one hand, statements from interviews gave a clear indication that the 
residents of Europe have behaved as a collective and suggest that they see themselves as a community, even distinct from adjacent settlements from which they not separated by visible boundaries (see Fig. 1). The community had long organised itself for fear of being moved to another site, and atypical term that has come up regularly in the interviews is 'thina abahlali base Europe', meaning 'we-the residents of Europe'. On the other hand, engagements with external actors, including various NGOs, party organisations and councillors, did reveal some cracks in the community. The community leadership of Europe has changed several times since 2012. One of the main differences between leadership factions has been strategic: whether the community should focus on local self-reliance efforts and engagement with external expertise or whether they should favour political mobilisation and demands for free services and houses from the state. Whereas the former involves cooperation with NGOs and knowledge exchange with planners and managers in the bureaucratic side of local government, the latter approach entails challenging the political side of local government. When this former, collaborative approach was challenged by a group of young ANC Youth League activists in 2012, they were described by their opponents as such

The newly elected leadership was a group of young people, who were passionate about politics but did not have the vision, skills and knowledge to take the community to the next level of development. Hence they had to forge a relationship with the leadership in Barcelona [adjacent settlement]. (former community leader, September 2012, personal communication)

The new leaders had subordinated Europe to an external leadership governing several informal settlements. While the leadership of Europe later shifted back to the former group of leaders, the constantly shifting demarcation of the local community made collaboration efforts unpredictable. It also, as we will come back to, affected efforts at systematising community knowledge.

\section{Mediating Community Knowledge and Expert Knowledge}

Whenever a project management or an external NGO attempts to engage in knowledge exchange practices with an informal settlement, it requires representatives which can be consulted. In South Africa, formal and informal systems of leadership-including ward councillors, ward committees, street committees and traditional leaders-all claim various levels of democratic legitimacy in urban localities. In our case studies, certain individuals were invited into positions as mediators between community and project personnel. Here, we label these local knowledge brokers, as our research finds knowledge claims to be central to this mediation.

In Joe Slovo, the most prominent knowledge broker has been the Joe Slovo Task Team. Community members set up the task team as a direct consequence of the N2 Gateway Project, and they also received a position in the Project Steering Committee as a result. Sometimes referred to as the 'government of Joe Slovo' by residents, they were granted privileged access to decision-making and information regarding the project. In the process, they became bearers of procedural and technical knowledge which put them in a powerful position in the community. The Task Team was a particularly 
important source of knowledge for those who were eligible for a house and were waiting for news on their allocation. Many were highly supportive of the Task Team and viewed them as legitimate leaders. Others, however, were critical:

The leadership does not share the information easily. It's as if they own the project. If you can ask me anything about the plans for this project I will not be able to tell you [...] Reporting to the community is selective and we cannot question any malpractices, we live in fear of being eliminated from the list if you criticise. (Joe Slovo residents, June 2013, personal communication)

A gap evolved between what was decided and known by managers and politicians, on the one hand, and what was decided and known by people living in Joe Slovo, on the other. The Task Team, the Project Steering Committee and appointed community liaison officers (CLOs) filled the mediation roles, sometimes through the same individuals. Responsibilities could involve relaying information about waiting lists, updating inhabitants on the construction process, recruiting people to casual jobs with the different contractors and facilitating community meetings. The role of local knowledge brokers became increasingly disputed as the project progressed.

In the Europe settlement, similar allegations were made against community leaders cooperating with external NGOs. In fact, allegations against these community representatives of not wanting to share the knowledge emerging from partnership meetings with local government were used to delegitimise their leadership. Some representatives of the competing leadership faction claimed that those Europe residents who collaborated with external NGOs and local government kept information to themselves and portioning out knowledge to their own networks and relatives. We will revert to the communication between Europe residents and the City of Cape Town later.

\section{Who Owns Community Knowledge?}

Attempts to systematise and codify knowledge that has hitherto only appeared as tacit or community-based knowledge will often invoke issues of ownership (Patel et al. 2012). In the case of Europe, the Community Organisation Resource Centre (CORC) employed experts to work with the community to create, among other things, a socalled enumeration report. Community members were equipped with tools to help them participate in planning for upgrading - including spatial layout, drainage systems and amenities - allowing them to report on their current living conditions in order to engage constructively with the state (CORC 2010). This creates what Epstein (1996: 293) refers to as the expertification of lay activists: community leaders who came through grassroots organisations and street committees were given the opportunity to receive training from external organisations.

However, the above-mentioned shift in leadership brought in a group of young people who did not feel a sense of ownership towards this method of data collection. The new leadership was never properly acquainted with the community mapping and survey techniques. According to their opponents, they were 'politically aligned and not in favour of the enumeration report'. Consequently, they did not disseminate the findings of the report to the local residents once it was finalised. And, instead of 
continuing knowledge exchange with local government officials and NGOs, the new leadership chose a more confrontational strategy.

We, the residents of Europe, together with those who live in informal settlements, we have no other way to express our grievances to get government to listen to our demands for upgrade in our area. One ability we have is to toyi-toyi, which means a visible, public protest. We bring normal life to a standstill in order to draw attention to our plight. We won't give up until the government responds to our demands. (Europe resident during a protest, October 2013, personal communication)

Subsequently, when some of the previous leaders were re-elected, CORC revived their engagement with Europe, initiating a plan for a crèche and a new multi-purpose community hall. This implies that residents again saw the use of the enumeration report and felt a sense of ownership to it. They have also since then engaged in drafting various community plans.

\section{Limited and Late Inclusion of Community Knowledge}

According to Piper (2012), who has done research on another upgrading initiative in Cape Town, a symptomatic characteristic of development interventions is how the role of communities is reduced to mere 'token' participation and that this participation only occurs in the implementation stages. We have identified a similar pattern in the Joe Slovo case. The N2 Gateway Project has been marked by a narrow use of knowledge since its initiation and planning phase. According to members of the community and municipal officials, project objectives were mainly formulated by national politicians wanting to make it their personal prestige project (Jacobs 2013). As a consequence, the desire to 'beautify' the N2 highway and the ability to showcase speedy housing delivery were prioritised over local concerns (Newton 2009). Because fast implementation was identified as a political objective, consultation was done neither with external expertise nor with representatives of the target community during the planning phase. Arguably, this has led to problems in later stages, such as a mismatch in housing supply and demand, contested ratios for beneficiary groups and continuous alterations in implementation (Author 2013).

The narrow use of community knowledge continued into the implementation stages of the project. At this point, responsibility for the project had been transferred from high-level politicians to a governmental housing agency. While a social compact had been signed and community members had officially been included in the Project Steering Committee, many residents expressed their discontent with the extent of participation in practice. The following statements reveal this disgruntlement.

We have no influence. Decisions are made elsewhere, we just get agree on what is already planned.

Decisions are made up there, what we do is to "rubberstamp"

(various Joe Slovo residents, June 2013, personal communication). 
Another problem which arised from such exchange is that even if knowledge was shared, it was done in ways which were not easily accessible to the residents of Joe Slovo. Interviewees expressed how 'the information given in the meeting was too technical and difficult for people to assimilate' and concern that 'in explaining the plans to the community some of the words and meaning might have been lost in the translation from English to isiXhosa'.

Public meetings were in fact held during the first phases of the project, although they were experienced by some as one-directional communication from project management to the community and not vice versa. Project managers seem to corroborate this in interviews, explaining how the meetings were mainly organised to inform the community.

Communicating with the community helps us when we need to rethink certain strategies. Because if there is a loud voice that says, we don't want this, we can mitigate in terms of managing risk. (senior project manager 1, February 2013, personal communication)

If you don't address them, they stop the project [...] But if you constantly address all of their issues, you're not going to go anywhere. (senior project manager 2, March 2013, personal communication)

In other words, knowledge sharing by project managers did not seem to be primarily motivated by actively wanting input from affected groups, but rather to prevent delays and disorder - as a risk management strategy.

\section{Appropriate and Inappropriate Knowledge}

In this upgrading projects, the challenge of local residents was not only to be heard and for their experiences and viewpoints to be included in the various upgrading processes. They also had to fight for their perspectives to be regarded as legitimate. However, this played out differently in the two cases.

In Joe Slovo, the group known as the Joe Slovo Residents Association claimed that they had valid concerns and viewpoints about the ongoing development that were not taken seriously by the project management and local authorities. They claimed that the community had 'rejected a medium-density, multi-storey solution', as was then planned (and later realised) in phase III of the N2 Gateway Project. To legitimate these claims, they referred to previous promises of the ANC government and to Xhosa cultural values.

African traditional practices prohibit us from living in flats. At times when we have to slaughter for sacrificial purposes we need a kraal to do the slaughtering, space to cook our traditional brew, and space for community members who would be attending the ceremony. (leader of social movement, March 2013, personal communication)

The Xhosa saying 'ukwazisa indlu yakho kwabaphantsi' means making the location of one's home known to one's ancestors, a cultural practice which requires both land and home ownership. It is important to reiterate at this point that the Residents' 
Association at this point had come to represent many people who were ineligible for a house in N2 Gateway, and these concerns were, therefore, by many, seen as a pretext to stall the project. After all, a de-densification would allow even fewer of the original Joe Slovo habitants to take up residence in the new houses. Hence, it comes as no surprise that such views were not allowed onto the Project Steering Committee, as explained by a senior project manager:

We would want to have the people who are still living in the shacks in the Project Steering Committee. Because then at least we know they will address the need of the community. Those people that live in the new houses, they don't really care anymore. And the non-qualifiers that are sitting in the committee, don't want the progress in the project because that means that they have to live somewhere else. Sooner than later. (senior project manager, March 2013, personal communication)

In Europe, on the other hand, the main legitimacy struggle was over area's suitability for upgrading. The City of Cape Town (CoCT), as the owner of the land, relied mainly on a technical assessment conducted by engineers to test the feasibility of the land. The government was concerned about the legal aspect and the financial viability of an upgrading solution. Conflict started when the CoCT declared Europe uninhabitable and a danger to the health and safety of its residents. One of the city officials commented on the development of the site.

To develop the site would present danger to the residents and the environment water will be contaminated and the emissions of methane gas from the rubbish underneath would endanger people's lives. The City of Cape Town can be held liable. Lastly developing the land would cost the City a fortune. (senior city engineer, April 2014, personal communication)

In this process, the CoCT mainly relied on technical expertise and did not include the lived experiences of people residing in Europe. Thus, decisions were made by the city for the residents, but not with the residents. This angered the Europe community, who did not see the same threats from continuing to live where some of them had lived for 20 years. The so-called hazards have been openly questioned by community leaders.

I was born here in Europe, I have not seen nor experienced any threat from living in this area, except for flooding during the rainy season (former community leader, March 2013, personal communication).

Much like the residents of the Argentinian settlement studied by Auyero and Swistun (2008: 367), people in Europe 'use[d] their own bodies as instruments of denial'. Moreover, there was insufficient communication between CoCT and the community around this assessment, leading people to rely on the knowledge that was available - their own experiences and hearsay. Conflicting knowledge claims over the habitability of Europe has continued throughout the period of research, also relating to the feasibility of a proposed technical solution to the problem: putting a 'clay cap' on top of the site to prevent emissions. 


\section{Perceived Risks of Knowledge Exchange}

In the literature arguing for more inclusive knowledge practices, there is an implicit assumption that sharing knowledge is mutually beneficial for all involved. However, knowledge exchange can be associated with risk, as we witnessed in both cases.

In Joe Slovo, community members treated NGOs who got involved in the early phases of the project with suspicion. Early on, CORC initiated an enumeration in Joe Slovo, and the shack counts and statistics from this report have arguably contributed to a more realistic planning of the N2 Gateway Project. Some critical voices, however, argued that the enumeration process was also instrumental in 'facilitating the unpopular relocations' (Huchzermeyer 2011: 145, our emphasis). Since the initial enumeration, residents have generally been reluctant to work with NGOs, with the exception of legal advice, irrespective of their stated intentions.

A similar issue surfaced in Europe, when the leadership that had been engaged with CORC, was ousted in 2012. A part of this collaboration was taking part in partnership meetings with service departments in the CoCT. However, the new leaders were hostile towards these engagements and alleged that the previous leadership withheld information with regard to the development of the area. The new chairperson also claimed that the enumeration document had been used by authorities to identify newly built shacks and extensions for demolition in their area (cf. Huchzermeyer 2011). This was based on an overall suspicion that the previous leadership worked closely with the CoCT in monitoring and governing the community. In their opinion, the service departments extending services and the City's Anti-Land Invasion Unit (ALIU) removing were one and the same thing. Admittedly, the ALIU is organised under the City's Informal Settlements Department, the same department responsible for upgrading of Europe and other settlements, which goes some way in explaining why people have conflated the different roles of local government.

These experiences show how residents might not want 'be known' by the authorities (cf. Skuse and Cousins 2007). They rather view knowledge exchange with external actors as potentially detrimental to their community (also see Patel et al. 2012). The establishment and maintenance of trust in such exchanges is therefore an absolute prerequisite.

\section{Conclusion}

Many have argued for including local knowledge in urban development projects. This article has addressed the role of knowledge politics in informal settlement upgrading through an empirical investigation of Joe Slovo and Europe informal settlements in Cape Town. While we are fundamentally sympathetic towards the ideals of inclusive knowledge management, the studies presented here portray the role of community knowledge through a critical lens. Efforts to engage with community knowledge - that is, the experiences and contextualised information among local residents - face a series of challenges in the two cases presented above. We identified problems of demarcation, mediation, ownership, timing, legitimacy and risk across the two cases which we believe is of relevance to similar initiatives elsewhere. The knowledge base for the N2 Gateway Project in Joe Slovo has been largely expert-driven, with limited input of 
community knowledge. Furthermore, local politics in Joe Slovo served to undermine the notion of a unified community whose 'community knowledge' can be engaged with. In both Europe and Joe Slovo, moreover, diverse knowledge alliances have been at work, with local government officials, various NGOs and activists. Through these exchanges, different residents have been included and excluded from knowledge exchange, partly with reference to the appropriateness of their claims and viewpoints. This is not necessarily problematic, if it serves to establish legitimate forms of representation and excludes elements that block decision-making and development efforts. But, local knowledge brokers gain exclusive access to information and procedures making them more powerful, sometimes undermining their legitimacy in the process. Also, if knowledge exchange is limited to the implementation phase of the project, as happened in Joe Slovo, it appears to function more as a mechanism to contain grievances than as substantial participation. Finally, if the community is to be involved from the initial planning stages, the exchange must be supported by a higher level of trust than was the case in Europe, where shifting leadership, uncertainty regarding the habitability of the land and shack demolitions strained relations between local government, community members and mediators.

\section{References}

Appadurai, A. (2012). Why enumeration counts. Environment and Urbanization, 24(2), 639-641.

Auyero, J., \& Swistun, D. (2008). The social production of toxic uncertainty. American Sociological Review, 73(3), 357-379.

Baud, I. S. A., \& Post, J. (2002). "New partnerships in urban solid waste management and their contribution to sustainable development: experiences in Accra (Ghana) and Chennai (India)". In Baud, I. S. A. and J. Post (eds) Realigning actors in an urbanizing world. institutions and governance in an international perspective. Ashgate, Aldershot: 217-239.

Baud, I., K. Pfeffer, J. Sydenstricker and Scott, D. (2011) Developing participatory spatial knowledge models in metropolitan governance network for sustainable development. Chance2Sustain Working Paper, Bonn, EADI: $1-20$.

Boulding, C., \& Wampler, B. (2010). Voice, votes, and resources: evaluating the effect of participatory democracy on well-being. World Development, 38(1), 125-135.

Bruckmeier, K., \& Tovey, H. (2008). Knowledge in sustainable rural development: from forms of knowledge to knowledge processes. Sociologia Ruralis, 48(3), 313-329.

Chambers, R. (1995). Poverty and livelihoods: whose reality counts? Environment and Urbanization, 7(1), 173-204.

Corburn, J. (2003). Bringing local knowledge into environmental decision making: improving urban planning for communities at risk. Journal of Planning Education and Research, 22(4), 420-433.

CORC (2010). "Europe household enumeration report. Gugulethu, Cape Town October 2010". Informal Settlements Network, Europe Community Leadership and Communicty Organisation Resource Centre joint report: 1-32.

Cornwall, A., \& Coelho, V. S. P. (2007). Spaces for change? The politics of participation in new democratic arenas. New York: Zed Books Ltd.

Eppel, S. (2007). "They come here and take our houses!”: community conflicts in Langa in the context of the housing crisis in Cape Town: 'Borners' against 'migrants'. Unpublished M. Phil. thesis in Development Studies, University of Cape Town.

Epstein, S. (1996). Impure science: aids, activism and the politics of knowledge. Berkeley: University of California Press.

Fischer, F. (2000). Citizens, experts and the environment: the politics of local knowledge. Durham: Duke University Press. 
Flyvbjerg, B., \& Richardson, T. (2002). Planning and Foucault: in search of the dark side of planning theory. In P. Allmendinger \& M. Tewdwr-Jones (Eds.), Planning futures: new directions for planning theory (pp. 44-62). London: Routledge.

Gibbons, M., Limoges, C., Nowotny, H., \& Al, E. (1994). The new production of knowledge, the dynamics of science and research in contemporary society. London: Sage.

Haraway, D. (1988). Situated knowledges: the science question in feminism and the privilege of partial perspective. Feminist Studies, 14(3), 575-599.

Hjorth, P. (2003). Knowledge development and management of urban poverty alleviation. Habitat International, 27(3), 381-392.

Hordijk, M., \& Baud, I. (2006). The role of research and knowledge generation in collective action and urban governance: how can researchers act as catalyst? Habitat International, 30(3), 668-689.

Huchzermeyer, M. (2011). Cities with 'slums': from informal settlement eradication to a right to the city in Africa. Claremont.

Jacobs, F. (2013). The challenge of housing the poor: stakeholders, politics and knowledge use in decisionmaking processes for the N2 Gateway Housing Project in Cape Town. Unpublished master thesis, Master of International Development Studies, University of Amsterdam, 1-93.

Jordhus-Lier, D. C. (2015). Community resistance to megaprojects: The case of the N2 Gateway project in Joe Slovo informal settlement, Cape Town. Habitat International, 45(3), 169-176.

Leach, M., \& Scoones, I. (2007). Mobilising citizens: social movements and the politics of knowledge. Brighton Institute of Development Studies, 1-34.

Massey, R. T. (2013). Competing rationalities and informal settlement upgrading in Cape Town, South Africa: a recipe for failure. Journal of Housing and the Built Environment, 28(4), 605-613.

Newton, C. (2009). The reverse side of the medal: about the 2010 FIFA World Cup and the beautification of the N2 in Cape Town. Urban Forum, 20(1), 93-108.

Patel, S. (2001). How can poor people benefit from research results? In: Utilization of research for development cooperation, linking knowledge production to development policy and practice. The Hague: RAWOO.

Patel, S., Baptist, C., \& D’Cruz, C. (2012). Knowledge is power-informal communities assert their right to the city through SDI and community-led enumerations. Environment and Urbanization, 24(1), 13-26.

Piper, L. (2012). Development trustees, not rent-seeking deployees: the designed meaning of community upgrading in the Violence Through Urban Upgrading Project, Cape Town. African Centre for Citizenship and Democracy Working Paper, 11, 1-22.

Rakodi, C. (2003). Politics and performance: the implications of emerging governance arrangements for urban management approaches and information systems. Habitat International, 27(4), 523-547.

Scott, D. (2011). The role of a spatial 'civic science' in repositioning scientific expert knowledge in society: a case from South Africa. Chance2Sustain, Bonn, EADI: 1-2.

Scott, D., \& Barnett, C. (2009). Something in the air: civic science and contentious environmental politics in post-apartheid South Africa. Geoforum, 40(3), 373-382.

Skuse, A., \& Cousins, T. (2007). Spaces of resistance: informal settlement, communication and community organisation in a Cape Town township. Urban Studies, 44, 979-994.

Van Ewijk, E., \& Baud, I. (2009). Partnership between Dutch municipalities and municipalities in countries of migration to the Netherlands; knowledge exchange and mutuality. Habitat International, 33(2), 218-226.

Watson, V. (2003). Conflicting rationalities: implications for planning theory and ethics. Planning Theory \& Practice, 4(4), 395-407.

Winkler, T. (2013). At the coalface: community-university engagements and planning education. Journal of Planning Education and Research, 33(2), 215-227. 